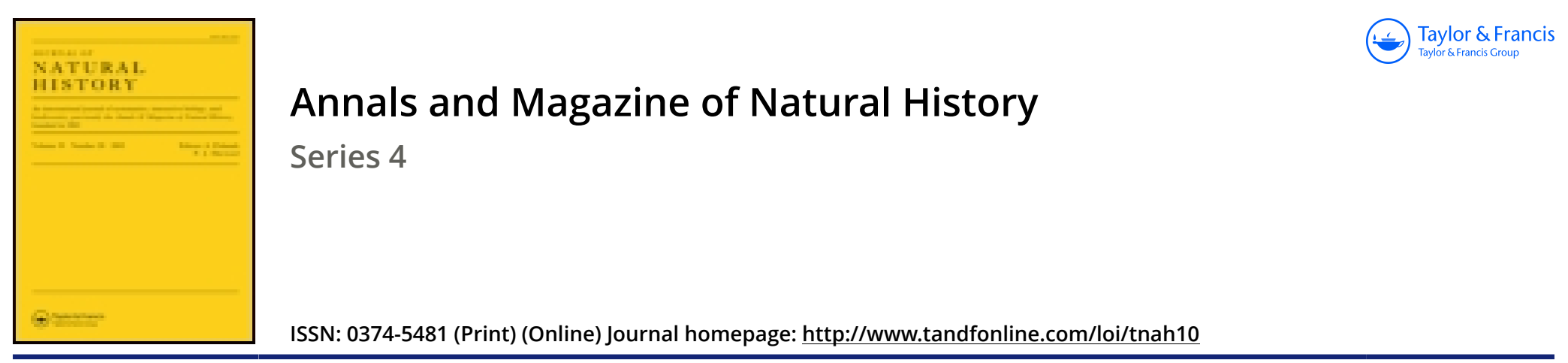

\title{
On Nearctos and Ælurina
}

\section{Dr.J.E. Gray F.R.S.}

To cite this article: Dr. J.E. Gray F.R.S. (1874) On Nearctos and Ælurina, Annals and Magazine of Natural History, 14:79, 93-93, DOI: 10.1080/00222937408680926

To link to this article: http://dx.doi.org/10.1080/00222937408680926

$$
\text { 曲 Published online: } 13 \text { Oct } 2009 .
$$

Submit your article to this journal 전

LII Article views: 4

Q View related articles $\asymp$ 
On Nearctos and \$lurina. By Dr. J. E. Grax, F.R.S. \&c.

Dr. Theodore Gill, in the 'Annals and Magazine of Natural History' for this year, xiii. p. 15, with his usual industry as a compiler, points out that I overlooked two generic names that have been used by Gervais in his ' Hist. Nat. Mammifères,' ii. 1855. Though this book bears the date 1855 , the second volume is not in the $\mathrm{Mu}$ seum Library, nor have $I$ seen it in any other scientific or other library in this country; and being a history of Mammalia intended only for popular use, it is scarcely a place in which a zoologist would look for a new genus.

Dr. Gill states that M. Gervais has established the genus Tremaretes on account of a "supracondyloid foramen of the humerus, in whieh it is said to differ from all other Ursidæ;" but Dr. Gill points out that this foramen is found in other Ursidx, and is doubtless exceptional and monstrous in them. I would ask, as only one skeleton of Ursus ornatus is known, may it not be an individuality in that specimen? Certainly it is a novelty in zoology to establish a genus on the existence or non-existence of a foramen in the humerus. My genus Nearctos is established on the pecnliarity in the form of the lower jaw, shown to be a characteristic peeuliarity by the examination of sereral skulls, a true zoological character.

In 1867, I established the genus Viverriceps for Felis Bennettii and several other Asiatic cats, because they have an elongate skull and a complete bony orbit. I referred Felis planiceps to this genus, because it had the same kind of skull-overlooking the peculiarity of its having a compressed donble-rooted first false grinder in the upper jaw, which is figured by De Blainville in his 'Ostéographie,' and that Professor Gervais had proposed the genus Ailurin (AElurina) for this animal in 1855; and Fitzinger called it Ailurogale in 1869.

I have examined four skulls of this species and find that the peculiarity of the false grinder is a permanent character of the species, and therefore propose, as Dr. Gill has done, to retain both EElurina and Viverriceps.

The front upper grinder of Viverriceps is subcylindrical and onerooted, and differs in size in different species. Thus, in Viverriceps Bennettii it is small and conical ; in Viverriceps Ellioti it is very small and rudimentary; it is similar in $V$. rubiginosa, but very soon falls out.

On the Metamorphoses of the Acarina of the Famities Sarcoptidæ and Gamasidæ. By M. Megniv.

In July and August of last year I communicated to the Academy two notes on the zoological position and physiological function of the little parasitic Acarina referred to the genera Hypopus, Homopus, and Trichodactylus, which, according to my observations, are merely the heteromorphous nymphs of certain Sarcoptidx-among others, of the Tyroglyphi.

Since this period I have continued my investigations of the meta- 